Faculty of Law, Administration and Management of Jan Kochanowski University in Kielce

Michą AdAm LeśnIEWSKI

Faculty of Law, Administration and Management of Jan Kochanowski University in Kielce

\title{
KNOWLEDGE GROWTH FACTOR FINANCIAL AWARENESS OF STUDENTS OF RZESZÓW UNIVERSITIES
}

\begin{abstract}
When dealing with it was found that the financial education increases substantially the economic knowledge to build awareness and competence of the younger generation and therefore the dissemination of this knowledge. The aim of this paper is to identify the importance of the knowledge economy in the growth of the build awareness and competence of the students in the management of finances in the current, constantly changing environment. Design development was subject to the hypothesis in accordance with that - there is a relationship of the knowledge economy and the increase of awareness and competence of the younger generation in achieving financial stability and their independence. This problem will be implemented using the analysis of the state of the knowledge economy university students of Rzeszów on individual economic areas. Method applied research area is anonymous questionnaire survey addressed directly using a survey to students study desktop and portable exams I and II degree.
\end{abstract}

KEYWORDS: knowledge economy, knowledge objective economic awareness, subjective knowledge 


\section{INTRODUCTION}

Quoting romantic Polish, poet and writer A. Mickiewicz: knowledge we can learn from other, but wisdom we must learn themselves. Science and money others you will enrich, wisdom you must itselfown himself. Sage ordinary people from the conversation assesses and exceptional men learns of silence.

Wisdom is the sum of knowledge and good. Therefore Seneka (1961, p. 411) recognized 'wisdom for superior excellence of the human soul. So understood wisdom is training. If we want to think about their own future, we need to go back to the old idea of education. The prerequisite for this is re-arrival times proper training. In the meantime, looking at present the education process this it currently technical character. It was reduced mainly to the formation of skills to respond to questions. Not significance of these features that are necessary for life in contemporary, globalised technical civilisation. This type of training should be supplemented by the competence and qualification, as well as another dimension or existential, understood yet by the older generation trainers. Remember that the essence of education is and will be shaping the human and acquire new ways of self-fulfilment, whether meanings and value of life of every man. The same meaning training must be directly related to the meaning of life. According to M. Horkheimer (2011, p. 240), training ...should be understanding of what celebrates us as people and not only as members of the public industrial, i.e., training should be a harmonious and comprehensive. May not be restricted only to the skills to communicate and operate and the use of electronic equipment (e.g. tablet, your computer). Next to the physical development or congenital advantages of intellectual training must include at the acquisition of analytical skills (draw conclusions), and therefore the sense of responsibility for the decisions. The so understood training drew attention M. Horkheimer (2011, p. 240): After this shortcuts that recently occurred, and in spite of its, I cannot abandon the hope that not only in the first period after the disaster and in the coming decades this forgotten already attitude is again the aim of university-level education. Limitation of study to acquire skills (...) is not enough. The judge deprived empathy means death of justice.

With this in mind, training is a condition of the spirit, which remains even when forget about all acquired all competence. 
However there are two main obstacles in the way of the so understood education. As can be observed, currently training is connected mainly with the process of absorption. Whereas the obstacle (the instructor), how stated one of my students on the exam with the insurance: why the lord, o Lord he requests from me such knowledge. I have it in hard memory? In response heard of me: this knowledge, which is contained in a hard memory is not your knowledge, known by Mr purposeful. It is not part of the Lord. This is not data media (PCS) must be fitted with an expected my knowledge, but the Lord must be developed.

The second obstacle results from the increasingly stronger differences between the world of the spirit that requires work and the world of changing successively technology, which causes us to get fired from this job. Contemporary globalisation process and the changing world of technological developments that is civilization many simplifications, contributes significantly to laziness. Technological changes that give rise to the Youth technical must be followed by wisdom - life wisdom. Already I. Kant (1986, p. 283) wrote that the wisdom of life is: no authority recognition is properly what we call stupidity and this troubles cannot be remedied. Head knife back or limited, whose absence of sound level common sense and its own concepts can be very well equipped know even. But since then usually lack of hint of wisdom (seconds Petri), this is not surprising that meets very scholars people who in the application of its science often disclose this lack not measurable repair.

The contemporary trend of the knowledge economy, including financial influenced materially to the attitudes on the demand side and supply side. Gain greater knowledge economy helps you recognize the opportunities and risks associated with the functioning of the market so that customers are able to make informed decisions, in particular the financial. This would enter the various levels of education in the field of education, including financial, taken at different stages of development of a society by the various stakeholders (e.g.: secondary education, higher, financial institutions, government etc.), as well as the level of financial knowledge represented by the Polish society. It should be remembered that financial education, as an economic education, awareness of economic assessment. You can talk about education advanced, based on a long and complex process of education at the stage of secondary or higher education (formal), where changes can be observed in the long term and 
education a brief, which is the result of the li only short-term memory, which arrives to the recipient from other broadcasters and the media. Whereas this separation awareness, for the purposes of this development, authors analyse an awareness of the advanced. With this in mind, the aim of this research is the identification of the level of knowledge as increasing the awareness of financial students from university of Rzeszów. It will be realized on the basis of the analysis of the knowledge of the subjective and objective students on issues in the field of economics, including issues of purely financial. Design development was subject to the hypothesis in accordance with that - there is a relationship between the level of the knowledge economy, including financial and increase awareness and competence of the younger generation in achieving financial stability, including their independence. Analysis of the surveys have been carried out on two planes: Theoretical and empirical. Theoretical analysis is based on the use of knowledge in the literature of both Polish and foreign policy. Empirical analysis used a presentation of the results of surveys carried out in 2016, among Academic Youth (study desktop and portable exams I and II), in the field of economic sciences, in discipline: economics, science management and finance, aged 20 to 30 years, making possible the assessment scale and projection of changes in the composition of economic awareness and financial during the subject.

\section{THE IMPORTANCE OF THE KNOWLEDGE ECONOMY IN THE PROCESS OF INCREASING THE AWARENESS OF FINANCIAL YOUNG GENERATION}

By Cate Lyons-Crew (Financial Inclusion Program Manager) (see: Iwanicz-Drozdowska 2011, p. 13; Fernandes, Lynch, Netemeyer, 2014, p. 1861-1883): financial awareness is necessary to function in a modern society and is increasingly important in the long term a dignified life and society. This understanding concepts and procedures economic, and also the ability to use this knowledge to solve economic problems. Here it should be borne in mind that:

1. This is not information but there is no information without data.

2. The information is not known but there is no knowledge without information.

3. Knowledge is not wisdom but no wisdom without knowledge. 
The same to speak of knowledge, including economic, must be met two basic conditions (ref.: Pacholarz, 2016, p. 13-14):

a) between the collection of data and the present analysis - a necessary condition and insufficient,

b) acquires information/e is interpreted by the human rights - a necessary condition and sufficient.

Otherwise the table:

a) data is not information,

b) information is not known.

The competence of the financial statements reflect the level of knowledge about the financial products and services and affect the ability to make effective financial decisions affecting well-being using (Walstad, 2017, p. 63-64). This requires in particular such capabilities that are limited to the capacity to analyse and financial management of the authors. Therefore the competence of the financial statements include such subcomponents you want as: knowledge, learning, understanding, selection, comparisons and selection. The International Organization INFE (International Network on Financial Education) operating at the OECD draws the attention to the mutual interaction of certain factors, acting that competence include financial connection awareness, knowledge, skills and attitudes and actions necessary to make the right choices so that ultimately the entity has financial prosperity (Measuring Financial Literacy, 2011, p. 3; Gustman, Steinmeier, Tabatabai, 2012, p. 309-313). The European Commission (EC) defines in turn powers as a financial ability of customers and small business owners to understanding of financial products so that they can make informed financial decisions (Habschick and others, 2007, p. 8; Roach, 2014, p. 74-84).

In view of the dynamic development of the financial markets, demographic change and economic subjects economic competence, including financial in recent years has particular significance. Change the needs of individuals as well as new and more sophisticated products sector financial market, and with them there is a need for knowledge, skills and competences to these needs in the best extent and as far to meet (table 1). 
Table 1.

The main determinants of the increase in the importance of the issues of competence in the field of economics

\begin{tabular}{|l|l|}
\hline \multicolumn{1}{|c|}{ Complexity of individual needs } & \multicolumn{1}{c|}{ The complexity of finance products } \\
\hline - increasing instability of working life, & - new distribution channels, \\
- lowering the level of social security, & - deregulation of financial markets, \\
- increased individual responsibility, & - wider choice of financial products, \\
- growing prosperity, & - greater dynamics of new product \\
- growing debt, & - movelopment, \\
- prolonged life span, \\
- increase in the number of self-employed
\end{tabular}

Source: study behind: (see: Habschick, Seidl, Evers, 2007, p. 5).

Systematic changes which are occurring in the financial services market (Przybytniowski, 2016, p. 93-125), and consequently has lived its entire life innovation in customer service, underline the importance of financial awareness. There is no division of the knowledge economy (Walstad, 2017, p. 63-64), prompts the young generation to the total lack of concern the functioning of the financial market and thus brings the demand side management to total financial exclusion. The absence or low level of education of economic, promotes to decisions by the young generation decisions which often lead to insolvency by the customer (Baicker, Mullainathan, Schwartzstein, 2015, p. 1623-1667).

The above considerations lead the authors of this development to the proposal that the primary role of education is to increase financial knowledge among the younger generation. This leads to the respective behaviour as well as make informed decisions in the management of finances. The main objective of economic education, including financial and is the young generation in the understanding of trends in the changing, globalised economic environment and know their rights and obligations (ref.: Ansoff 1968, p. 37-44; Andrews 1998; Gryffin 2002, p. 74-93; Romanowska 2010, p. 7-15; Leśniewski 2015, p. 171-187; Przybytniowski 2013, p. 63-67, Busom, Lopez-Mayan, Panadés, 2017, p. 74-92). 


\section{KNOWLEDGE OF THE SUBJECTIVE AND OBJECTIVE}

In the knowledge of an objective shall take into account the things "true”. This knowledge is at the same time their own good and general. Is above all - rationalism in providing all the information (not „sell”) knowledge based on objective defined data. This knowledge, does not bear the characteristics of the emotional, flowing from inside the unit. The person providing knowledge objective - directs the justice and true reality (ref. Popper 1992, p. $52^{1}$ ). However, whereas the subjective knowledge, the person providing the information has its prejudices, personal respects, experiences, liabilities stemming from the inside. This knowledge is "unilateral” - often incompatible with the assessment of reality (table 2). In the case of secondary schools or universities (Busom, Lopez-Mayan, Panadés, 2017, p. 74-92), basic media knowledge is teacher or lecturer at universities who have both subjective knowledge (not available), or individual, difficult to formalise and objective (non-confidential).

Table 2.

\section{Knowledge subjective and objective}

\begin{tabular}{|c|c|c|}
\hline & $\begin{array}{l}\text { Knowledge implicit (hidden, } \\
\text { not available) }\end{array}$ & Knowledge evident (available) \\
\hline$\frac{\tilde{0}}{\frac{0}{0}}$ & $\begin{array}{l}\text { - individual - difficult to copy, } \\
\text { - leaves the inside of us (on experience), } \\
\text { - focus (used by many people in many } \\
\text { places at once) - here and now, } \\
\text { - subjective, } \\
\text { - whizz (analogy) - practice }\end{array}$ & $\begin{array}{l}\text { - intersubjective (available for more than } \\
\text { one - company) - easy to transfer, } \\
\text { - knowledge on the outside of the US (leaves } \\
\text { - the rational understanding), } \\
\text { - sequential - there and then, } \\
\text { - objective, } \\
\text { - theory }\end{array}$ \\
\hline
\end{tabular}

Source: based on (ref. Nonaka and Takeuchi 2000, p. 96).

Characteristics of knowledge an open and hidden were I. Nonaka and H. Takeuchi (2000, p. 84). They wrote of the mutual relations between them. They considered that the knowledge the implicit is by way of communication. A process that requires a kind of distributed processing approaches as individual skills, experience, information theoretical and practical, i.e. competence communication sender (figure 1). 
Figure 1.

General model communication

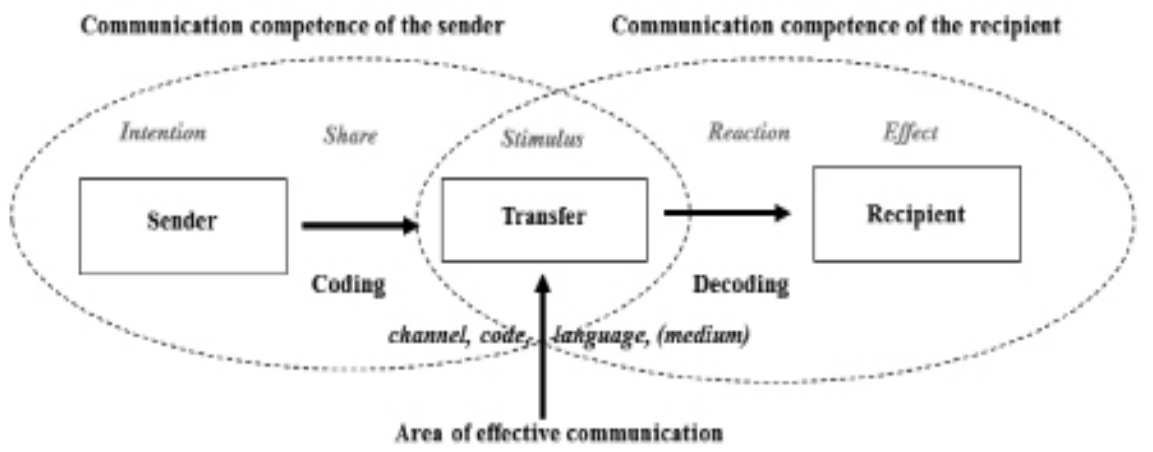

Source: Own (Nonaka and Takeuchi 2000, p. 84; Dennis, Fuller, Valacich, 2008, p. 575-600).

Knowledge available, so-called excepted, is transmitted in the form of information using a variety of data sources, which is facing the theory outside the text. Provides the knowledge in the education process is created in a spiral (Nonaka and Takeuchi 2000, p. 96), where processes: socialisation internalisation combination and externalisation - complement each other and are, in the cycle of transmission and processing of the information that a new knowledge students or students. De facto they generate new knowledge by using the process of interaction with/or lack of practical training. Harmonisation of knowledge explicitly is the end of the process of reaching the expected knowledge (truth) about the new topic (subject) - its sources of origin.

\section{RESEARCH METHODOLOGY}

\section{Methodology}

In the development were used methods of analysis qualitative comparative analysis and statistical analysis. For the collection of the material of the original authors used the results of the survey conducted in 2016 year, and on the study of knowledge and awareness of the financial. This questionnaire contains general part, including questions related to metric respondents and part of a detailed, relating to the assessment of the status of the subjective, objective and sources of knowledge and preferred forms of economic education, including financial students. 
The assessment of the level of knowledge and awareness of the financial students were made in the representations Likerta scale, with which the authors obtain can answer associated with the acceptance of the phenomenon. The proposed scale consisted of the cafeteria, which connects five replies arranged on the total acceptance - „5”, to total rejection - „1”. Tested student was to determine to what extent agrees with the specified question where: „1” - meant „strongly small”, „2” - meant „small”, „3” - meant „medium”, „4” - meant „high”, „5” - meant „strongly high”.

The selection of the sample provide the representativeness of the results for students aged from 18 to 30, in terms of gender and place of residence. The choice of this ensures the comparability of the results, as I mentioned before, conducted in earlier years, carried out within the framework of the statutes. In both cycles research, attempt consisted of 315 people, which made it possible to carry out analyses in more detailed (table 3 ). In this test was attended by students on desktop and portable exams I and II, universities of Rzeszów, studying in the field of economic sciences, in discipline: economics, sciences fund and finance. Accounted for the most numerous group respondents studying specialities: finance and accounting, management, banking and insurance: in turn - 101 $(32,1 \%), 92(29,2 \%), 73(23,1 \%)$ and $49(15,6 \%)$. Among all responders persons outnumbered students study portable exams - $\mathrm{II}^{\circ}$. Including comprised -212 $(67,3 \%)$ examined people, while the number of students studies $\mathrm{I}^{\circ}$ was 103 $(32,7 \%)$. In the examined group exceed slightly women 166 (52,7\%).

Most respondents were in the age 26-27 years and 24-25 years, sequentially $(25,1 \%$ and $21,6 \%)$. They constitute the $46,7 \%$ of all examined patients. Least tested students were over the age of 30 years $(9,8 \%), 20-21$ $(13,3 \%)$ years as well as $28-29(15 \%)$.

\section{The RESUlTS OF}

\section{Subjective assessment of the status of the knowledge economy among students}

In the statement of the number of properly cast answers by students, it can be noted that all students answered the set of questions contained in the survey. 
In the first instance students study desktop and portable exams I and II degree answered the question related to the subjective assessment of the knowledge economy financial, management and economics: Sampled answered the question: How Do and their general knowledge of economic, financial and management? Whether your and knowledge is...? On the basis of the results obtained, students consider that their knowledge of economics, Finance and life sciences management is at "strongly small” and „small” (including indicators in 2014 were until 48,1\%, a 2016 - 46,4\%. In the further students have identified their state of knowledge at the level of the medium and in 2014 - 39,8\% and in 2016 - 37,9\%. As can be seen in the period considered increased interest of evaluators your knowledge economy as „strongly small” and „small”, for these respondents who assess it as "high” and „high”. In addition, compared to the year 2016, almost 4\% increase in the number of assessors their knowledge as: „strongly small” and „small”, for students evaluators it as "high" and ",high”.

The next step is to analyse the subjective assessment of the knowledge economy, including financial in selected slices demographic (place of residence and age), where students answered the question: How Do and its general knowledge of Economics, Finance and life sciences helpful? Whether you're and knowledge is...? By analysing the data obtained, students estimate worse condition of its knowledge at the age of 20-21 years, residing in rural areas. In comparison with the year 2014, increased by more than $2 \%$ of the number of respondents assessing their knowledge as: „strongly small” and „small”, for respondents evaluators it as "medium" and more than 3\% - as "high" and "high". Students who declare that their knowledge is the medium level are over the age of 30 years and 28-29 years residing city from 100 to 500 thousand inhabitants and above 500 thousand inhabitants. In relation to the year 2014, nearly $3 \%$, in both cases, an increase in the number of test, evaluating their knowledge as "high" and "high”, at the expense of students indicating it as "medium” and by more than $4 \%$ „strongly small” and „small”. At this point, it can be concluded that your students at age has a significant impact on the level of aid response. This is linked to the fact that respondents in different age begin work professional that studies nomadic (especially grade), which are also a source of knowledge-economy and thus the awareness of financial assistance. 
Another question related to subjective assessment of knowledge, was to determine its in different areas: How do and the level of their knowledge and skills related to...? Whether you and knowledge is...? Whereas the area in which the students to assess the state of their knowledge (figure 2), preferably to drop the ability to manage finances.

Figure 2.

How do and the level of their knowledge and skills related to...? Whether you and knowledge is ...? (N $2016=315)$

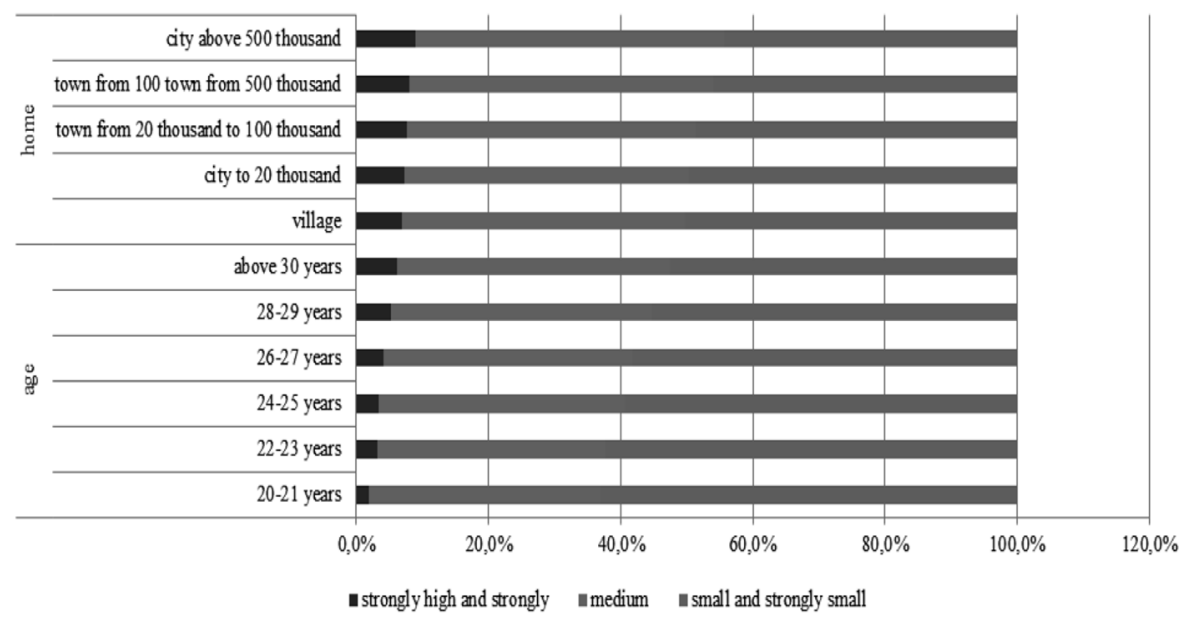

Source: Own.

Whereas the year 2016 in virtually all areas of increased interest students Evaluators their knowledge as „strongly high” and „high”. While decreased group those students who evaluate your knowledge as a „small” and „small” and „medium”.

By analysing the data obtained, taking into account: year of studies, degree and whether they are stationary studies or nomadic, it can be stated that the stage of tertiary determines the status of the knowledge economy students. Slightly higher level of knowledge students $\mathrm{II}^{\circ}$ in compared with the students of the $\mathrm{I}^{\circ}$. Noteworthy is the fact that students $\mathrm{I}^{\mathrm{o}}$ begins the process of studying, have a higher average (3,35\%) from students finishing education $(3,21 \%)$. The reverse situation took place students $\mathrm{II}^{\circ}$. Students of the first year were 
average at 3,12\%, and students of the second year have reached an average of less than 2 percent higher $-4,87 \%$.

The next step in the research were analysis of knowledge gaps and skills among women and men (figure 3). Students have to answer the question: How do and the level of their knowledge and skills related to...? Whether you and knowledge is...?

Figure 3.

How do and the level of their knowledge and skills related to...? Whether you and knowledge is...? $(\mathrm{N} 2016=315)$.

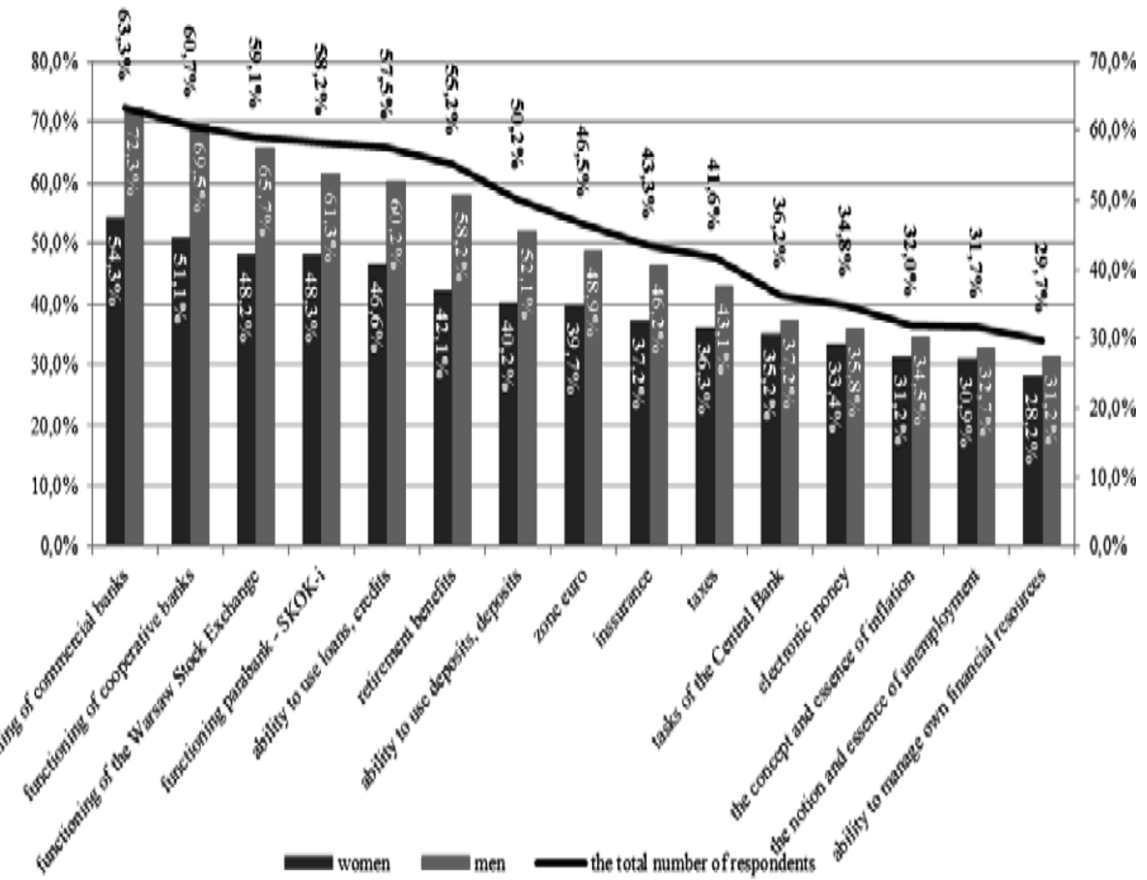

* in figure the greater the value, the less knowledge in the area Source: own.

Both men and women the lowest evaluate your knowledge with the functioning of the banking market (commercial banks and cooperative and the functioning of the Warsaw Stock Exchange). In the vast majority of rural women evaluate your level of knowledge of the lower than men. The biggest 
difference in subjective level of knowledge between women and men is in areas: retirement benefits and the functioning of the cooperative banks and the Warsaw Stock Exchange. While the lowest difference has occurred in the areas of: jobs Central Bank, concept and the essence of the inflation and in e-money. In virtually all areas there is less self-esteem women than men. Whereas the age of respondents, the largest gaps in knowledge, regardless of age, concern: banking sector, insurance, pension benefits and the euro area. The largest differences in subjective assessment of the level of knowledge between the newest and oldest age group, noted in: retirement benefits, concept and the essence of the inflation and the euro area.

Objective assessment of the status of the knowledge economy students at

An objective assessment of the status of the knowledge economy students at was made on the basis of the results of the questionnaire as well developed indicators of the knowledge economy, constructed on the basis of specific questions of management, of economics and finance. Related questions were among others with: ability to manage their own portfolio financial knowledge of the banking, insurance (Chen, Wong, Lee, 2003, p. 303-328; Agarwal, Mazumder, 2013, p. 193-207) pensions, rules save and invest, issues related to unemployment and inflation, the functioning of the zone and the euro currency, use of loans and credits, of non-cash transactions and the knowledge of the tax system.

Analysis of the test of the knowledge economy, i.e. response respondents on specific questions, showed that the knowledge students study desktop and portable exams I and II is much better than their subjective assessment. More than half of the valid questions has granted over $45 \%$ (strongly large, high), and nearly $25 \%$ of students replied to the medium level. Less than 6 correct answers has granted over $13 \%$ of respondents, which gave strongly small' level of the knowledge economy. In comparison to the tests carried out in 2014 (the same questions), the percentage of students, which may be classified to the group of high, medium and low level of the knowledge economy, slightly increased, but does not give a significant statistical difference. One of the easiest questions for students has proved to be a question relating to manage their own financial resources. Just 43 respondents indicated an incorrect answer, which gives less than $14 \%$ of total corresponding to this question. In 
the further minor problems meant question related to the smart card - almost 28\%. A similar result to the previous issues appeared the unemployment 103 persons most often correct option, which gives $32,7 \%$ of the total corresponding to. Most problems with the reply have students with question regarding: the functioning of the banking sector (193 person - 61,3\%), the euro zone (182 person $-57,8 \%)$, retirement benefits (169 person - 53,7\%) and insurance $(160-50,8 \%)$ all responders students. Compared to the year 2014, increased interest of students, which comply with the correctly on almost all questions (for the four questions, changes were significant). The largest increase (nearly $26 \%$ ) were observed for questions related to electronic money. Whereas the data obtained, it is difficult to clearly indicate that your age had an impact on the level of response. Students between 24-27 (9,8\%) Empire the ability to properly complete the survey and respondents aged 20-21 (18,7\%) - had, according to the lowest level of financial knowledge. The results of that age range of 24-27 years, living in large cities have the most answers, as confirmed by the results obtained from the assessment of the subjective.

In the final part of the research a comparison of the subjective and objective assessment of the shortcomings of the knowledge economy among responders students. Businessmen believe that have the least knowledge in the functioning of the banking sector, the concept and the essence of inflation and knowledge of social insurance and economic. Relatively sampled better been unable to questions relating to manage their own financial management and electronic money.

\section{Conclusions}

As a result of the studies carried out, has been implemented. The analysis of the level of the knowledge economy students from universities of Rzeszów has enabled verification that has been put at the outset article hypothesis. In the development has been confirmed hypothesis there is a relationship of the knowledge economy and the increase of awareness and competence of the younger generation in achieving financial stability and their independence.

Following the above considerations, compared to 2014, although there were significant changes in the level of the knowledge economy test students. Still, almost half of students has significant shortcomings in this area. 
Noticeable changes are in the following areas:

a) a subjective assessment of the knowledge economy where increased a significant proportion assessments relating to knowledge „small” and "strongly low” for assessments „strongly high” and „high”,

b) subjective sense of knowledge is higher in 2016 in relation to the year 2014.

On the basis of the studies carried out, it was found that there were no significant between gender, age, the place of residence and economic knowledge students regardless whether he studies at the desktop and portable exams of the first and second degree.

\section{References}

Andrews, K.R. (1998). The Concept of Corporate Strategy, [in:] H. Mintzberg, J.B Quinn, S. Ghoshal, The Strategy Process, revised edition, New Jersey: Prentice Hall Europe. ISBN 9780136759843.

Agarwal, S., Mazumder, B. (2013). Cognitive abilities and household financial decision making, "American Economic Journal: Applied Economics" 5(1). ISSN 1945-7782.

Ansoff, H.I. (1979). The changing shape of the strategic problem, [in:] D. Schendel, C. Hofer (eds.), Strategic management: A new view of business policy and planning, Boston: Little Brown and Co. ISBN 9780316773126.

Baicker, K., Mullainathan, S., Schwartzstein, J. (2015). Behavioral Hazard in Health Insurance, "Quarterly Journal of Economics", vol. 130(4). ISSN 0033-5533.

Busom, I., Lopez-Mayan, C., Panadés, J. (2017). Students' persistent preconceptions and learning economic principles, "The Journal of Economic Education”, vol. 48(2). ISSN 1349-4058.

Chen, R., Wong, K.A., Lee, H.C. (2003). Age, period, and cohort effects on life insurance purchases in the U.S., "The Journal of Risk and Insurance" 68(2). ISBN 1539-6975.

Dennis, A.R., Fuller, R.M., Valacich, J.S. (2008). Media, tasks, and communication processes: A theory of media synchronicity, "MIS Quarterly", vol. 32 (3). ISSN 02767783.

Fernandes, D., Lynch, J.D., Netemeyer, R.G. (2014). Financial literacy, financial education and downstream financial behaviors, "Management Science", 60(8). ISSN 0025-1909. 
Gustman, A.L., Steinmeier, T.L., Tabatabai, N. (2012). Financial knowledge and financial literacy at the household level, "American Economic Review", 102(3). ISSN 0002-8282.

Griffin, R.W. (2002). Podstawy zarzadzania organizacjami, [Organization management basics], Warszawa: PWN [in Polish]. ISBN 8301140186.

Habschick, M., Seidl, B., Evers, J. (2007), Survey of Financial Literacy Schemes in the EU27, VT Markt/2006/26H - Final Report, Hamburg, November.

Horkheimer, M. (2011). Odpowiedzialność i studia, przekład translatoryjny pod kierunkiem $\mathrm{H}$. Walentynowicz, [Responsibility and study, translated by $\mathrm{H}$. Walentynowicz], „Kronos” [in Polish]. ISSN: 1897-1555.

Iwanicz-Drozdowska, M. (2011). Edukacja i świadomość finansowa. Doświadczenia $i$ perspektywy, [Education and Financial Awareness, Experiences and Perspectives], Warszawa: Szkoła Główna Handlowa [in Polish]. ISBN 9788373786226.

Kant, I., (1986), Krytyka czystego rozumu, t. I, tłum. R. Ingarden, [Criticism of pure reason, vol. 1, translation R. Ingarden], Warszawa: Państ. Wydaw. Naukowe [in Polish]. ISBN 8301036699.

Leśniewski, M. (2015). Wiedza w strategiach zarządzania przedsiębiorstwem. Zarzqdzanie wiedza. Studium teoretyczne, [w:] J. Jaskiernia, R. Kubicki (red.), Ekonomia, zarządzanie i rozwój regionalny. Pomiędzy światem polityki a życiem naukowym, tom trzeci, Kielce: Uniwersytet Jana Kochanowskiego, [Knowledge in business management strategies. Management of knowledge. Theoretical study, [in:] J. Jaskiernia, R. Kubicki (ed.), Economics, governance and regional development. Between the world of politics and scientific life, the third volume], Kielce: Jan Kochanowski University in Kielce [in Polish].

Measuring Financial Literacy: Questionnaire and Guidance Notes for Conducting an Internationally Comparable Survey of Financial Literacy. (2011). OECD/INFE, Paris.

Nonaka, I., Takeuchi, H. (2000). Kreowanie wiedzy w organizacji, [Creation of knowledge in the organization], Warszawa: Poltext [in Polish]. ISBN 8386890991.

Popper, K.R. (1992). Wiedza obiektywna:ewolucyjna teoria epistemologiczna, [Objective knowledge of evolutionary epistemological theory], Warszawa: PWN [in Polish]. ISBN 8301104899.

Przybytniowski, J.W. (2013). Konkurencyjność rynku usług pośrednictwa ubezpieczeniowego $w$ Polsce, [Competitiveness of the market of insurance brokerage services in Poland, Managerial Publishing House], Warszawa: PTM [in Polish]. ISBN 9788361949176. 
Przybytniowski, J.W. (2016). Wspótczesne funkcje i mechanizmy transmisji między sektorem ubezpieczeniowym a sfera realna gospodarki. Teoria i praktyka, [Modern functions and mechanisms of transmission between the insurance sector and the real economy. Theory and practice], Warszawa: CeDeWu [in Polish]. ISBN 9788375567588.

Roach, T. (2014). Student perceptions toward flipped learning: New methods to increase interaction and active learning in economics, "International Review of Economics Education", vol. 17. ISSN 1477-3880.

Romanowska, M. (2010). Przełomy strategiczne w przedsiębiorstwie [Strategic breakthroughs in the enterprise], [w:] Studia i Prace Kolegium Zarządzania i Finansów, „Zeszyty Naukowe”, Nr 98, Warszawa: Szkoła Główna Handlowa, [in Polish]. ISSN 1234-8872.

Seneka, L.A. (1961). Listy moralne do Lucjusza, tłum. W. Kornatowski, [Moral Letters to Lucius, W. Kornatowski's translation], Warszawa: PWN, [in Polish].

Walstad, W. (2017). Editor note on submission guidelines and financial education, "The Journal of Economic Education", vol. 48, (2). ISSN 1349-4058.

\section{Endnotes}

According to this author, scientific rationality is unambiguously connected with the way science evolves, in view of adopting a critical attitude towards the emerging theories. According to this theory, all your efforts should be directed towards creating new theories to falsify the predictions, rather than lead to another confirmation of verification. Only constantly criticized and questioned knowledge has come up, it can lead to systematic creation of the more perfect theories, because sometimes what we see nowadays, it can be „we were wrong” and consequently we can learn from our own mistakes and draw conclusions. Admit - we made a mistake. 
